\title{
The Existence of Academic Document on Development of Legal Drafting
}

\author{
Ismet Hadi ${ }^{1}$, Suslianto ${ }^{1}$, Siti Nur Setia Rahman ${ }^{2}$ \\ ${ }^{1}$ Lecturer of the University of Muhammadiyah Gorontalo, Indonesia \\ Received: September 15, 2020 \\ Received in Revised: October 24, 2020 \\ Accepted: November 6, 2020
}

\begin{abstract}
This research purpose to comprehending Indonesia as a legal state, the state is obliged to carry out the development of national law committed in a planned, cohesiveness terpadu, and sustainable in the national legal system that ensures protection of the rights and obligations of all the people in Indonesia based on constitution 1945. Indonesian legal state has characteristic because Pancasila as a basic of law which has differential with the other country that based on west law, such as deliberation, social justice and a law which based on national interest and Indonesian unitary Indonesia which protect the Indonesian homeland. This research is a normative legal research that uses methods of analysis perspective. Most of the data obtained through the library research which done by examining library materials such as books, journals, research report and sekunder data which study about legal drafting. This research show that, firstly, politic of law as a legal frame work and role to create isu contituendum. President before amendment of constitution 1945 has authority to establish laws, and The House of Representatif (DPR) has authority to give enactment of draft. After amendment constitution 1945 there are shift of power that the legislator's authority in the hands of the House. Second, the existence of an academic document in each drafting legislation to provide an overview of the results of scientific research that underlie design of any proposed legislation that will be presented and discussed in the House.
\end{abstract}

Keywords: Academic Document, Politic of Law, Governmental System

\section{Introduction}

Regulation is the basis of a rule of law, a state whose government is subject to the law. As stated in the 1945 Constitution of the Republic of Indonesia (UUD NRI), Indonesia is a constitutional state, not based on mere power. According to van der Vlies \& Doludjawa, (2005). initially what was contained in the definition of "rule of law" was only the government's attachment to the law. By binding the government to the law, the same treatment by the government for everyone is more secure, thus there is legal certainty. Asshiddiqie, (2005) Argues that further revealed that every legal norm must produce a certainty value (certainty, zekerheid), justice (equity, billijkheid), and utility.

Amendments to the 1945 Constitution (UUD 1945) cannot be separated from the crystallization of democratic ideas from various components of the nation and a reflection on the journey of state and national life for several decades. K. C Wheare revealed, a constitution is changed only with careful consideration, and not for simple or haphazard reasons. The aim of the amendment to the 1945 Constitution is to improve the basic rules for implementing democratic and modern state governance, among others, through a firmer distribution of power with the principle of strict and transparent checks and balances.

The result of the amendment to the 1945 Constitution places the process of law formation at a different extreme, namely executive power to legislative power. The paradigm shift in the legislative function is carried out by strengthening the role of the DPR, which is accomplished 
by cutting the legislative function of the government. Hierarchically, the position of the law lies under the UUD, the law further regulates the provisions of the Constitution. Basically, the material of the law is an order contained in the constitution, although in its development many laws were made to meet the needs of state administration outside the explicit mandate of the constitution and also the needs of the community.

The substance of a law is influenced by many factors, including the issue of the personal institutional capacity of the DPR to carry out its legislative functions. Another factor that is also important to explore further is the relationship between the substance of a law and its drafting. The formation / drafting of laws in Indonesia after reform is regulated by Law Number. 10 of 2004 concerning the Formation of Legislative Regulations (Law No. 10 of 2004) then amended by Law No. 12 of 2011 concerning the Formation of statutory regulations (Law No. 12 of 2011).

Referring to Law 12 of 2011, the process of drafting a bill must be preceded by an academic text which is a requirement in drafting laws and regulations. . Academic Manuscripts are not new in the framework of the formation of a draft law in Indonesia, this was previously the National Law Development Agency (BPHN), which issued a technical manual for the preparation of Academic Texts, through the Decree of the Head of BPHN No.G-159.PR.09.10 1994 concerning Technical Guidelines for Preparation of Academic Papers of Legislation which, among other things, describes the name / term, form and content, position and format of the Academic Manuscript.

Academic papers are one way to minimize overlapping bills. A good academic paper will be very helpful for drafters of draft laws in making legal norms, decision makers, judges to decide cases, especially those related to judicial review, because debates can be traced to a norm.

For the sake of the realization of a good statutory regulation, and to meet the need for the regulation of various existing problems, the use of an Academic text in the process of drafting a bill is very important. In the preparation of a draft law, an academic text is indispensable for the formation of a draft law. The objectives are, among other things, so that the resulting law is in line with the national legal system, is in accordance with (demands) of the life of the community, and can minimize problems in the future. Based on the background of the above problems, there are two problems that can be formulated, namely how is the legal politics of the formation of laws? How is the arrangement of academic papers in the formation of laws? What is the urgency of academic papers in the formation of laws?

\section{Methods}

The research entitled "The Usefulness of Academic Papers in the Process of Formulating a Draft Law" uses the normative juridical research type, by examining the normative juridical concept associated with research variables which include: (1) the political background of the law on the formation of statutory regulations; (2) dynamics of the institutionalization of academic texts as a requirement for drafting laws; (3) the urgency of an academic paper as a requirement for the formation of laws and regulations.

\section{Results and Discussion}

\section{The Politics of Law in the Formation of Legislation}

In the strictness system of Indonesia, up to now, the constitution has formally changed four times, namely: (1) the 1945 Constitution; (2) the Constitution of the Republic of Indonesia (RIS Constitution); (3) the Provisional Constitution of the Republic of Indonesia (UUDS); (4) The 1945 Constitution of the Republic of Indonesia which was amended (amended) with four changes. According to Soehino (1990) this resulted in different forms of legislation that could 
be issued during the validity period of the respective constitutions. Based on this, the power to form laws at each validity period of a constitution is different from one another. This is understandable because the content of each constitution varies according to the understanding in the government system adopted at each period, namely:

\section{Formation of Laws for the Period 1945-1949}

During the second session, the legislative function was only discussed when discussing the draft Articles of the draft constitution proposed by the minor committee. Throughout the discussion of the articles conducted by BPUPKI, there has never been a question about the provisions contained in Article 3 of the two drafts. The idea that develops in BPUPKI, the President and the DPR are jointly forming laws. With the strong spirit of the President and DPR together in shaping laws, it is not correct to say that the legislative function in BPUPKI is a function that is practiced in the presidential system.

During the Soekarno government - Moh. Hatta was formed, the DPR institution has not yet been formed, under such circumstances, Article IV of the transitional rules of the 1945 Constitution stipulates that "before the MPR, DPR, and Supreme Advisory Council were formed according to this Constitution, all powers were exercised by the President with the help of the National Committee." This led to the formation of the Central Indonesian National Committee (KNIP) as an "assistant" to the President. However, on the way the Vice President Decree No. X which stipulates "that the Central National Committee, prior to the formation of the MPR and DPR, was entrusted with legislative powers and took part in determining the outlines of the state direction."

With this announcement, the power to form laws at that time was in the hands of the President and the KNP, which in practice was delegated by the KNP to the Central National Committee Worker Body (BP-KNP). For the smoothness of the formation of the BP-KNP law, it is assisted by a committee that is tasked with examining a draft law before it is discussed in the BP-KNP plenary meeting with the relevant ministers for decision.

\section{Establishment of Legislation from 1949 to 1950}

The journey of the new state of the Republic of Indonesia did not escape the pressure of the Dutch who wanted to return to power in Indonesia. By making Indonesia a union state, it would make it easier for the Dutch to re-colonize Indonesia. Within a deadline of about two years, the Netherlands succeeded in establishing a new state in the context of establishing the Republic of the United States of Indonesia (RIS).

In 1949 there was a Round Table Conference between the Netherlands and Indonesia in The Hague, which resulted in an agreement on the agreement on the transitional constitution text named the Constitution of the Republic of the United States of Indonesia on December 27, 1949, which was divided into 16 states of the Republic of the United States of Indonesia (RIS). The 1949 RIS Constitution consists of 197 articles and an annex representing a mixture of conceptions, principles of institutions from various sources of the state administration.

The RIS Constitution of 1949 regulates that the power to form laws and regulations rests with the President, DPR and Senate, there are at least 6 (six) articles in the RIS Constitution which regulate the power to form laws and regulations, namely: (1). Article 127 letter (a); (2). Article 128 paragraphs (1, 2, and 3); (3). Article 131; (4). Article 132 paragraph (1 and paragraph 2); (5). Article 133 paragraphs (1 and 2); (6). Art 134.

Based on the provisions of Article 127 and Article 128 of the RIS Constitution, there are three state institutions that act as the executing powers of the formulation of laws. However, if one looks closely, the Senate's involvement in the making of laws is limited to specific matters 
concerning one, several, or all of its parts or parts, or specifically regarding the relationship between RIS and the regions mentioned in Article 2. Apart from that, the formulation of laws remains the power of the Government and the DPR to discuss them together.

The 1949 RIS Constitution affirms the parliamentary system of government as stated in the 14 November Declaration. Isra (2010) revealed the character of the parliamentary government system in the RIS constitution, namely: (1) The separation between the head of state and the head of government, the head of state is carried out by the President, while the head of government is carried out by the prime minister; (2) As head of state, the president's power cannot be interfered with; (3) Ministers are responsible both individually and collectively. That is, if the policy of ministers or ministers is not accepted by the House of Representatives then the minister or cabinet must resign; (4) Legislative institutions are representative bodies with a two-room system(bicameral system)so that the functions of legislation are carried out jointly.

\section{Establishment of Legislation from 1950 to 1959}

The dissolution of the RIS state, as stated by Law Number 7 of 1950, on August 15, 1950, declared the entry into force of the new constitution. The 1950 Constitution applies to the entire territory of the Unitary State of the Republic of Indonesia. In the 1950 UUDS, the arrangement of the draft law is carried out by the government together with the approval of the DPR which is regulated in Article 89 to Article 100.This is in accordance with Article 89 of the 1950 UUDS which states:

"Except as provided for in Article 140, the statutory powers, in accordance with the provisions of this section, are exercised by the Government together with the House of Representatives."

At the time when the 1950 UUDS came into effect, the types of existing laws and regulations included: Basic Law, Law, Emergency Law, Government Regulation, Presidential Decree, namely: regulations for implementing Presidential Decrees, Presidential Regulations namely regulations for implementing Presidential Decrees. , Presidential Decrees, Prime Minister Regulations, Ministerial Regulations, Ministerial Decrees, Regional Regulations Level I and II. Types of statutory regulations other than those stated in the constitution are based on Presidential Letter Number 2262 / HK / 1959 dated 20 August 1959, Number 2775 / HK / 1959 dated 22 September 1959, and letter No. 3639 / HK / 1959 dated 26 November 1959.

During the time the 1950 UUDS came into effect, there was chaos in the order of the laws and regulations. There is confusion regarding the type and substance of statutory regulations, such as the Presidential Decree and the Presidential Decree regulating the material of Laws and Government Regulations. There is a Government Regulation which turns out to be an implementing regulation of the Presidential Decree. So, in this case there are various confusion and overlaps regarding the content material and the order of the laws and regulations.

Entering 1966, the types and order of laws and regulations began to be addressed, starting with the MPRS Decree No. XIX / MPRS / 1966 concerning Review of State Legislative Products other than MPRS products that are not in accordance with the 1945 Constitution. The 1945 Constitution and statutory regulations whose content is not in accordance with or contradicts the contents of the 1945 Constitution.

The regulation regarding the formation of legislation in the 1950 Provisional Constitution is carried out jointly by the government and the DPR. Isra (2010) revealed that in order to fulfill the "joint" requirements, the 1950 Provisional DPR Standing Orders stipulated that every bill originating from the DPR was submitted to all ministers before being discussed by the Special Committee or Section. The 1950 Provisional DPR has discussed 237 proposed bills, of which 
167 were approved into laws, then 64 laws were withdrawn and others had no further settlement.

The temporary 1950 Constitution could not last long, only about eight years. In accordance with its temporary nature, in the articles section there are legal provisions governing a permanent constitution-forming institution called the Konstituante whose members are elected through general elections. With the re-enactment of the 1945 Constitution, and remembering that the state institutions as outlined by the 1945 Constitution are not yet complete, several steps will be taken, namely: (1) Renewal of the composition of the House of Representatives through the Presidential Decree No. 3 1960; (2) Preparation of DPR Gotong Royong (DPRGR) with presidential decree No. 5 of 1960; (3) To implement the Dektrit issued Presidential Decree No. 2 of 1959 concerning the Provisional People's Consultative Assembly; (4) The preparation of the Provisional People's Consultative Assembly (MPR) was carried out with the Presidential Decree No. 12 of 1960; (5) Issued Presidential Decree No. 3 On the Provisional Supreme Advisory Council.

\section{Establishment of Legislation from 1959 to 1999}

From 1959 to 1999 , the administration of classified state governments in two periods, namely:

\section{Period 1959 - 1966 (old order)}

Although the Presidential Decree of 5 July 1959 ended the validity period of the Provisional Constitution of 1950 and the parliamentary system of government, the formation of laws and regulations was still carried out in a joint discussion pattern between the President and the DPR, both the bill originating from the government and the bill originating from the DPR's initiative were discussed together after there is an initial discussion in the DPR. However, in fact the formulation of these laws and regulations was carried out under the control of the President, especially after the conflict between President Soekarno and the DPR in 1960. From this conflict President Soekarno dissolved the DPR as a result of the 1955 General Election. Royong.

\section{Period 1966 - 1999 (new order)}

After the end of the old order government in 1966, the DPR-Gotong Royong on June 9, 1966 issued a memorandum entitled the DPR-GR Memorandum concerning the Orderly Sources of Law of the Republic of Indonesia and the Order of the Legislation of the Republic of Indonesia. The DPR-GR Memorandum contains: (1) An introduction containing the background for the suppression of the PKI movement; (2) Source of Orderly Law of the Republic of Indonesia; (3) Form and Order of the Legislation of the Republic of Indonesia; and (4) Chart / Schematic of the Composition of Power in the Republic of Indonesia.

This DPR-GR Memorandum was later appointed in the Provisional People's Consultative Assembly Session of the Republic of Indonesia (MPRS) in 1966 (20 June - 5 July 1966) as the content of MPRS Decree Number XX / MPRS / 1966. In the Form and Order of the Legislation of the Republic of Indonesia the hierarchical types of laws and regulations are listed as follows: (1) UUD 1945; (2) Mpr (Tap MPR) Provisions; (3) Law/Regulation Of The Replacement Government (Perpu); (4) PeraturanPemerintah; (5) KeputusanPresiden; (6) Other implementation regulations such as: Ministerial Regulation; Ministerial instruction; and others.

With the mandate of TAP MPRS No. XLI / 1968 concerning the Main Duties of the Development Cabinet, Suharto formed the Development cabinet and replaced the enhanced Ampera Cabinet. During the New Order era, the formation of laws and regulations was carried out based on the direction of the State Policy Guidelines (GBHN). The pattern of approach to the formation of laws can be said to be more emphasized on the initiative to form legislation 
from the initiating agency which is regulated by Presidential Instruction Number 15 of 1970 concerning, conceptually, the management of the management and drafting of the bill lies with the government.

With regard to the process of drafting a bill, the history of statutory regulations records that at least since August 29, 1970, all Ministers and Heads of Non-Departmental Government Agencies (LPND) must refer to Presidential Instruction of the Republic of Indonesia Number 15 of 1970 concerning Procedures for Preparing a Draft Law. -Law and Draft Regulations of the Government of the Republic of Indonesia (Inpres No. 15 of 1970). At that time, the consideration for the enactment of the Presidential Instruction was to create legal order and improve coordination, integration and synchronization of the administration of government tasks.

\section{History of Academic Manuscript Arrangements in drafting}

\section{Arrangement of academic manuscripts based on the Decree of the Head of the National Legal Entity in 1994}

In the Decree of the Head of BPHN, it was stated that: "the academic paper of statutory regulations is a preliminary text which contains the regulation of material in a particular field of legislation which has been studied systemically, holistically and futuristically from various aspects of science." These laws and regulations have sprung up, such as the term draft of the bill, scientific draft of the bill, scientific draft of legislation, academic draft of the bill, academic draft of the drafting of legislation. This decision of the Head of BPHN has become a guideline in the preparation of academic papers carried out at BPHN and within the Government.

Four years later, to strengthen the Decree of the Head of BPHN in 1994, the government issued Presidential Decree No. 188 concerning Procedures for Preparing the Draft Law. However, the Presidential Decree is not explicit in requiring initiators to prepare an academic paper in advance to compile a draft law. Because the weakness point is regulated in Article 3 in a Presidential Decree which states: (1) Ministers or Leaders of institutions that initiate the draft legislation can also first draw up an academic draft on the bill to be drafted. (2) The preparation of academic design is carried out in conjunction with the Ministry of Justice and its implementation can be submitted to universities or other Third Parties who have expertise for it. The word "can" in submitting a bill which means that an academic paper does not have to be made for a proposed bill submission. This means that the preparation of a bill may be preceded or without the preparation of an academic paper. The implication of this regulation is that many bills are submitted without being accompanied by academic papers.

\section{Arrangement of Academic Manuscripts Based on Law No. 10 of 2004}

Law Number 10 of 2004 concerning the Formation of Legislative Regulations (Law No.10 of 2004), does not explicitly regulate Academic Texts, but mentions the involvement of other parties outside the legislative and executive institutions in every drafting of a statutory law. which is referred to as community participation. Referring to Article 18 paragraph (3) of Law no. In 2004, the Presidential Regulation No. 68 of 2005 concerning Procedures for Preparing Draft Laws, Draft Government Regulations in Lieu of Laws, Draft Government Regulations, Draft Presidential Regulations (Presidential Decree No. 68 of 2005).

In Presidential Decree No. 68 of 2005, the Institutionalization of Academic Manuscripts "appears" explicitly in Article 5 paragraphs (1) and (2) of the Presidential Decree Number 68 of 2005 , it is stated that the existence of academic texts in the preparation of laws and regulations in Indonesia is not an obligation that must carried out in the framework of drafting 
laws, including Regional Regulations. Thus, the position of an academic paper can be considered only as a "support" for drafting a bill.

Then to follow up on Presidential Decree No. 68 of 2005, the Minister of Law and Human Rights issued Ministerial Regulation No. M.HH-01.PP.01.01 Year 2008 concerning Guidelines for Preparation of Academic Paper on the Draft Laws and Regulations (PerMenkumham No.1 of 2008), Academic papers at least contain the philosophical, juridical, sociological basis, subject matter and scope of material to be regulated, as well as the bill.

In general, the Academic Paper contains the urgency, conception, foundation, legal basis and principles used as well as thoughts on norms that have been poured into the form of articles by proposing several alternatives, which are presented in the form of a systematic and accountable description. in legal knowledge and in accordance with the political law that has been outlined. In line with this arrangement, Isra (2010) revealed that in an academic text, at least the following elements are described, namely: (1) Positive legal inventory results; (2) Inventory results of legal issues encountered; (3) Ideas on legal material that will be poured into the draft legislation; (4) Conception of the foundation, the basis of the law and the principles to be used; (5) The thought of its norms that have been poured into the form of chapters; (6) The initial idea of the draft legislation is systematically drafted: chapter by chapter, as well as article by article to facilitate and accelerate the implementation of the draft legislation.

\section{Academic Manuscript Arrangement Based on Law No. 12 of 2011}

Basically, before the enactment of Law no. 12 of 2011, an academic paper is not a necessity in the process of drafting a bill, but an academic paper is needed in the formation or preparation of a bill. According to Article 1 Paragraph (11) of Law Number 12 Year 2011, Academic Manuscripts are the results of research or legal studies and other research results on a particular problem that can be scientifically accounted for regarding the regulation of the problem in a Bill, Draft Provincial Regulation, or Draft District / City Regional Regulations as a solution to community legal problems and needs.

It is at this planning stage that it requires an in-depth and comprehensive study of scientific theory or thought related to the content of the Bill. This scientific thinking leads to the preparation of philosophical, sociological and juridical arguments in order to support the need or not the need for drafting a bill. The philosophical basis is meant that the regulations that are formed take into account the view of life, awareness, and legal ideals which include the mystical atmosphere as well as the philosophy of the Indonesian nation which originates from Pancasila and the Preamble of the 1945 NRI Constitution. community needs in various aspects. The real sociological foundation concerns empirical facts regarding the development of problems and needs of society and the state. Juridical basis is a consideration or reason that illustrates that regulations are formed to solve legal problems or fill legal voids by considering existing rules, which will be changed, or which will be revoked in order to guarantee legal certainty and a sense of public justice. The juridical basis concerns legal issues relating to the substance or material regulated so that new laws and regulations are formed.

\section{The Urgency of Academic Manuscripts as the Basis for Drafting a Bill}

\section{Conceptual review of academic manuscript preparation}

The preparation of an academic paper is a continuation of Mochtar Kusumaatmadja's idea, whose function is to provide guidelines for the formulation of a draft of legislation that will be established by the government. Academic manuscripts in the drafting process of the Bill are portraits or maps of various matters related to the legislation to be published. With the 
Academic Manuscript it will be seen and tested, whether in the bill there are rules and norms that are in line with the 1945 Constitution or not.

The formulation of an academic paper in a bill implies how at an ideal level, the law can provide benefits and guarantees protection for the community. In such conditions, theorists, academics and legal scientists have contributed greatly to creating an academic paper for a regulation to be made. Academic manuscripts are not formed without a definite purpose. The function of academic papers in the formation of statutory regulations is as: (1) Initial material that contains ideas about the urgency, approach, scope and content of a statutory regulation; (2) Consideration materials used in the application for permission for the drafting of the Bill / RPP to the President; and (3) The basic material for drafting legislation.

Academic papers are very important in the process of drafting a law when faced with statutory problems which have so far been considered not always responsive, not egalitarian, not futuristic and generally of low quality. The formation of laws in Indonesia has several problems, ranging from the too strong flow of political interest groups or certain interests of power holders who want certain things to be passed in the process of its formation, to ordered products that will benefit certain parties, with without seeing as a whole and developing values and the wishes of the wider community. For this reason, it can be justified that a law is a resultant product, namely that the product of legislation is often a product of the interests of certain groups who want something to be passed and can be enforced.

\section{Academic Manuscript as a Condition of Submission of Draft Law}

The formulation of an academic paper in a draft law implies how at an ideal level, the law can provide benefits and guarantees protection for the community. In such conditions, theorists, academics and legal scientists contribute greatly to creating an academic paper for a regulation that will be made, through certain scientific forums to discuss a topic of problems originating from the community, by making an inventory of problems found in the field after carrying out survey in several places. Academic Manuscripts do not only synchronize laws and regulations (both vertically and horizontally) but also pay attention to the philosophical basis in this case Pancasila. Therefore, in the Academic Manuscript there should be a special section that explicitly states in full the connection between the values of Pancasila and the substance of the draft / draft of the Bill that is being prepared by placing guiding principles that are inseparable from the values of Pancasila.

With respect to conflicts that arise in the implementation of statutory products due to not being compiled based on the value of life and not being obeyed by the community, it is necessary to prepare study materials in order to determine the consistency of the direction to be achieved by determining the studies that must be carried out in compiling a draft of a statutory product and examine regulations that are inconsistent with juridical, sociological, and philosophical aspects. This can also reduce pressure from foreign parties, so that Indonesia has certain laws that may not be in accordance with the values that live and are obeyed in the community. The tendency of the public's view to place legislation as a product that only favors the interests of the government (politics) so that in its implementation the community does not really feel that they own and live the laws. Therefore, it is hoped that Academic Drafts can be used as a filtering instrument, bridging and efforts to minimize the elements of political interest from the parties forming the laws and regulations, in which Academic Drafts are made by researching, accommodating and scientifically accommodating the needs, and expectations. society, then the community feels they have and live the legislation.

The existence of an academic paper in the drafting of the bill is very strategic and is an inevitable necessity in forming a good statutory regulation (Dias et al., 2013; Aragón-Correa 
\& Rubio-Lopez, 2007; Rollin, 2006). This is because in the development of the Indonesian state administration juridically there are still not many complete legal rules to regulate everything. Meanwhile, the flow of change desired by the community is very strong, especially for products of legislation that are responsive and aspirational. More people demand the existence of a statutory regulation not the will of the ruler alone. However, it is necessary to have public spaces that allow people's aspirations to be accommodated in the preparation of the substance of the bill.

\section{Community Involvement in drafting the bill}

The importance of the public to be involved in the formation of laws is based on the premise that the DPR has three functions, namely legislation; budget; and monitoring of it is carried out in the framework of people's representation (Suseno, 2019; Muheeb, 2015). This means that the activities of the DPR institutions still provide the people as a central point in carrying out their duties. Provisions for public participation in the formation of laws are regulated in Article 96 paragraph (2), (3), and paragraph (4), Law no. 12 of 2011.

Law Number 12 of 2011 in lieu of Law no. 10 of 2004 has regulated public participation in the formation of laws and regulations, especially the formation of laws, which is regulated in a little more detail than before. Based on Article 96 of Law no. 12 of 2011, the public can provide input orally and / or in writing in the formation of laws and regulations, which input can be made through: public hearings; work visits; socialization; seminars, workshops and/or discussions

The community is the object of the enforcement of a norm that exists in the law so that the community should be involved in the process of making a law, so that the aspirations of the community can be accommodated in the law (Wendel, 2001; Platteau \& Abraham, 2002). By including the aspirations of the community, the application of norms in the law will get a more positive response from the public.

Through public participation, it is hoped that laws and regulations will have advantages in terms of effectiveness of enforcement in society (Anani et al., 2020). In addition, participation also provides legitimacy or political support from the community for the formation of laws and regulations. The DPR as an institution that holds the legislative function is required to open the widest possible door to public participation. Indonesia as one of the most populous countries is of course a necessity to have laws and regulations that are pro-people and at the same time protect the interests of the people and aim at the welfare of the people as a form of accountability for state administrators.

\section{Conclusion}

Political law as a general framework that forms law (legal frame work) has an important role. Political law is an effort to realize the ius contituendum (actual law) and the current law is the law of the ius constitutum (a law that still has many faults, or there are still mistakes). Because legal politics is a discipline that underlies the activity of selecting and harmonizing various values, methods, or models that will be used in carrying out legal development in order to achieve goals or for the benefit of planned legal changes. The impact of the Amendment to the 1945 Constitution of the Republic of Indonesia, apart from changing the system and constitutional structure of the Republic of Indonesia in particular, has also placed the position of the DPR as the holder of power to form laws. The shift in power to form laws from the President to the DPR is a constitutional step that precisely places the functions of these institutions in accordance with their respective areas of duty. With this shift in power, the distribution of power theory with the supremacy of the MPR, which was previously adhered to as separation of power with the principle of mutual supervision and balance as an inherent 
characteristic, was abandoned. Historical records of the institutionalization of academic texts in statutory regulations have experienced ups and downs in a number of the regulations themselves. In 1994, through the Decree of the Head of the National Legal Entity issued a technical manual for an academic manuscript. This decision of the Head of BPHN has become a guideline in the preparation of academic papers carried out at BPHN and within the Government, which is based on the Presidential Decree No.188 of 1998 concerning Procedures for Preparing Draft Laws and Draft Government Regulations, but regarding the arrangement of academic texts itself only applies within the government (executive) only. Then the Presidential Decree was revoked and replaced by Presidential Decree No. 68 of 2005 concerning Procedures for Preparing Draft Laws, Draft Government Regulations and Draft Presidential Regulations.

\section{References}

Anani, S., Mashudi, I., \& Ariyasanti, D. (2020). Analysis of Local Government Implementation Report Model (LPPD) in North Bolaang Mongondow Regency, North Sulawesi Province. Journal La Sociale, 1(5), 19-23. https://doi.org/10.37899/journal-lasociale.v1i5.170

Aragón-Correa, J. A., \& Rubio-Lopez, E. A. (2007). Proactive corporate environmental strategies: myths and misunderstandings. Long range planning, 40(3), 357-381.

Asshiddiqie, J. (2005). Konstitusi dan Konstitusionalisme Indonesia. Jakarta: Sekretariat Jenderal dan Kepaniteraan Mahkamah Konstitusi RI.

Dias, P., Freedman, A., Medway, P., \& Par, A. (2013). Worlds apart: Acting and writing in academic and workplace contexts. Routledge.

Isra, S. (2010). Pergeseran fungsi legislasi: menguatnya model legislasi parlementer dalam sistem presidensial Indonesia. RajaGrafindo Persada.

Muheeb, I. O. (2015). The legislature and representative government in Ogun state Nigeria, 1999-2011 (Doctoral dissertation).

Platteau, J. P., \& Abraham, A. (2002). Participatory development in the presence of endogenous community imperfections. Journal of Development Studies, 39(2), 104136.

Rollin, B. E. (2006). The regulation of animal research and the emergence of animal ethics: a conceptual history. Theoretical medicine and bioethics, 27(4), 285-304.

Soehino (1990). Hukum Tata Negara, Teknik Perundang-undangan. Edisi Kedua. Cetakan Pertama. Yogyakarta: Liberty

Suseno, I. (2019). Forms of Ideal Laws of State-Owned Enterprises in Harmony with Article 33 Paragraph IV of the Preamble of the 1945 Constitution of the Republic of Indonesia. JL Pol'y \& Globalization, 85, 99.

van der Vlies, I. C., \& Doludjawa, L. (2005). Buku pegangan perancang peraturan perundangundangan. Direktorat Jenderal Peraturan Perundang-Undangan, Departemen Hukum dan Hak Asasi Manusia RI.

Wendel, W. B. (2001). Nonlegal regulation of the legal profession: Social norms in professional communities. Vand. L. Rev., 54, 1953. 